\title{
EFFECT OF ROOTING MEDIUM, CUTTING TYPE AND AUXIN ON ROOTING OF PEPINO (SOLANUM MURICATUM AITON) CUTTING
}

\author{
AgHDAEI, M. ${ }^{1}-$ NeMATI, S. H. ${ }^{1 *}-$ SAMIEE, L. $^{2}-$ ShARIFI, A. ${ }^{3}$ \\ ${ }^{I}$ Department of Horticultural Science, Faculty of Agriculture, Ferdowsi University of Mashhad, \\ Iran \\ ${ }^{2}$ Department of Ornamental Plants, Research Center for Plant Sciences, Ferdowsi University of \\ Mashhad, Iran \\ ${ }^{3}$ Department of Ornamental Plant Biotechnology, Academic Center for Education, Culture and \\ Research, Branch of Khorasan Razavi, Iran \\ *Corresponding author \\ e-mail: nemati@um.ac.ir \\ (Received 27 $7^{\text {th }}$ Nov 2018; accepted $2^{\text {nd }}$ Jul 2019)
}

\begin{abstract}
To investigate the effect of rooting medium, cutting type and auxin (indole butyric acid (IBA)) on rooting of pepino cuttings (Solanum muricatum Aiton), two separate experiments were carried out in a factorial based on completely randomized design. In the first experiment, the effects of two types of cuttings (middle and distal) and eleven rooting media, and in the second experiment, the effects of three levels of IBA $\left(0,500\right.$ and $\left.1000 \mathrm{mg} \mathrm{L}^{-1}\right)$ and seven rooting media (selected based on the results of the first experiment) on the rooting rate of cuttings and some growth characteristics including root length, the longest root length, stem length, fresh and dry weights of root and plant were evaluated. The results of the first experiment showed that the distal cuttings showed better rooting than the middle ones. The highest number of roots (40.5) was found in peat moss + perlite rooting medium. The highest averages of root length and length of the longest root were related to the distal cuttings planted in water and then in peat moss + perlite medium. The greatest root fresh weight was recorded in cuttings planted in peat moss + perlite medium, and the highest root dry weight and plant fresh and dry weights were obtained in distal cuttings planted in peat moss + sand medium. The results of the second experiment also showed that the highest (66) and lowest (26.76) numbers of roots were due to peat moss + perlite and water media, respectively. The greatest root length and length of the longest root was observed in the treatment of $0 \mathrm{mg} \mathrm{L}^{-1}$ IBA in water medium which was higher than in other treatments Moreover, the highest root fresh and dry weights were related to a treatment of $500 \mathrm{mg} \mathrm{L}^{-1}$ IBA in peat moss + sand medium. In general, the most suitable combination for pepino cultivation is the use of distal cuttings treated with a concentration of $500 \mathrm{mg} \mathrm{L}^{-1} \mathrm{IBA}$ and planting in the rooting medium of peat moss + perlite, followed by peat moss + sand medium.
\end{abstract}

Keywords: IBA, peat moss + perlite medium, root number and length, distal cutting, root fresh weight

\section{Introduction}

Pepino (Solanum muricatum Aiton), a member of the Solanaceae family, is a tropical and semi-tropical crop and native to the Andean Mountains. It is grown commercially in countries such as Bolivia, Colombia, Ecuador, Peru, Australia and New Zealand for its edible fruits, which are juicy, fragrant, sweet and rich in color and shape. It contains $92 \%$ water, low calories, high minerals, thiamine, niacin, riboflavin and ascorbic acid (Prohens et al., 1996; Sudha at al., 2011). Pepino is a greenhouse crop with growing season longer than most greenhouse crops and has a yield of 70-80 tons per hectare (Prohens and Nuez, 1999). 
Pepino propagation is possible through sexual and asexual methods, and most of the pepino cultivars are fertile and produce live seeds (5 to 30 seeds per fruit). Low percentage of seed germination, high levels of heterozygosity, and low quality of plants are the most important problems resulting from seed propagation (Pauli, 1988; Hernando and Leon, 1994; Pierik, 1997; Nemati and Tehranifar, 2007). There is not much information about the sexual reproduction of this plant, and generally reproductive propagation has been reported to be difficult and with low success. The germination rate of pepino seeds in soil has been reported to be only 4\%, so cutting is the main propagation method of this plant (Bhardwaj et al., 1996; Hrbans et al., 1996; Prohens et al., 2005; Nemati and Tehranifar, 2007).

In various studies, it has been determined that type and position of cutting and rooting medium have a significant effect on the success of rooting. So that in some herbaceous species such as olive (Aboutalebi Jahromi and Hassanpoor, 2003) and Azadirachta indica (Palanisamy and Kumar, 1997), distal cuttings had better rooting than the middle or basal ones. Culture medium is composed of substances that can replace natural soil for plant growth, in which roots grow continuously by absorbing water and nutrients (Douglass et al., 2009). Use of culture media started in the 1960s by using organic substrates such as peat (Schie, 1997), and today the use of granulated substrates for planting greenhouse vegetables has become very common and becomes more important every year (Gül et al., 2005). An ideal growth environment for the plant should include features such as being affordable and accessible, appropriate efficiency for physical support of the plant, ability to store water and food, adequate oxygen exchange for root respiration, high water holding capacity and appropriate drainage. Moreover, culture medium should be free of pathogenic organisms (bacteria, nematodes, fungi and insects), weeds, toxic substances and chemical residues (pesticides) (Johnson et al., 1985; Cantliffe et al., 2003). Although different materials are used to prepare plants growth medium, the final selection of the material type depends on the inherent characteristics of the culture medium to maintain the desired growth of the plant (Verdonck et al., 1982). In a study, the effects of cutting type, different levels of naphthalene acetic acid and three substrates were investigated on sum of root length of 'Consuelo' pepino cuttings. Using middle cuttings treated with naphthalene acetic acid at concentration of $500 \mathrm{mg} / \mathrm{l}$ and planted in perlite medium was reported as the best combined treatment (Nemati and Tehranifar, 2007). Although use of cutting is considered as the main propagation method of pepino plant and many reports indicated that pepino cuttings stablish roots easily, none of them intensively compared rooting intensity of cutting type, effects of various rooting medium and growth regulators (IBA) on it. Moreover, there is a report on unsuccessful rooting and vegetation propagation of the cuttings of the plants grown from the seeds of the Ramses and Consuelo cultivars (Nemati and Tehranifar, 2007). Since low success of pepino propagation through seeds is a major problem in the development of this crop cultivation, this study was conducted to investigate the effects of rooting substrate, cutting type and different concentrations of indole butyric acid on the rooting of pippino cuttings of the 'Ramses' cultivar.

\section{Materials and methods}

In this research, in order to evaluate the effect of rooting medium, cutting type (cuttings position) and auxin (indole butyric acid) on rooting of pepino cuttings, two separate experiments were carried out based on a completely randomized design with 
three replications in Ferdowsi University of Mashhad, Iran in 2016. In the first experiment, the effects of cutting type (distal and middle cuttings) and 11 rooting media including peat moss, perlite, cocopeat, sand, water, peat moss + perlite, peat moss + cocopeat, peat moss + sand, perlite + cocopeat, perlite + sand and cocopeat + sand were investigated on rooting of pepino cuttings (Fig. 1). Pepino seeds were purchased from Plant World Seed Company, UK, and planted in a greenhouse under temperature of $25^{\circ} \mathrm{C}$ and relative humidity of $50 \%$.

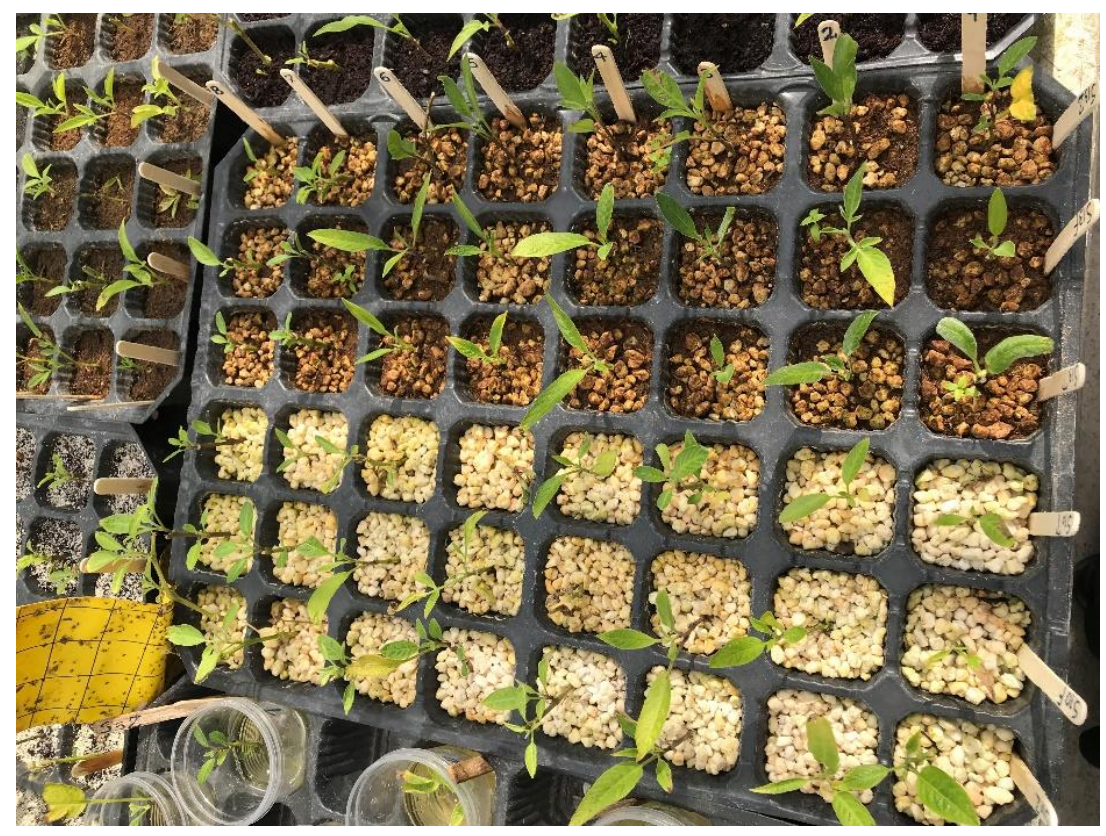

Figure 1. Culture media and cuttings

Two types of middle and distal cuttings with the length of $15 \mathrm{~cm}$ were prepared from the plants grown from seeds (seedlings) and planted in different media disinfected with benomyl fungicide. In the second experiment, the effects of different concentrations of indole butyric acid (IBA) $(0,500$ and $1000 \mathrm{mg} / \mathrm{l})$ and seven rooting media including peat moss, perlite, sand, water, peat moss + perlite, peat moss + sand and perlite + sand in six replications were evaluated on rooting of the cuttings and some growth parameters of pepino cuttings. Plants were grown in the greenhouse condition and temperature was set between $20^{\circ} \mathrm{C}$ day $/ 15^{\circ} \mathrm{C}$ night and pots were tap watered each 3 days. It should be noted that the choice of cuttings type and rooting media in the second experiment was carried out based on the results of the first experiment. For this purpose, $5 \mathrm{~cm}$ of the basal portion of the cuttings was treated with different levels of indole butyric acid for 10 seconds, and after drying, they were planted in different rooting media disinfected with benomyl fungicide. After four weeks, characteristics including total number of roots, root length $(\mathrm{cm})$, length of the longest roots $(\mathrm{cm})$, root fresh and dry weight $(\mathrm{g})$, stem length $(\mathrm{cm})$ and plant fresh and dry weight $(\mathrm{g})$ were evaluated. Data were analyzed using analysis of variance (ANOVA) procedure. The comparison of means were tested with the least significant difference test (LSD) at 5\% probability level. The SAS software (version 9.3) was used for analysis. 


\section{Results and Discussion}

Data showed that distal cuttings had better rooting. The highest number of roots and greatest root fresh weight were recorded in cuttings grown in peat moss + perlite medium. Moreover, the highest averages of root length and length of the longest root were observed in water and then in peat moss + perlite medium. However, the highest root dry weight and plant fresh and dry weights were obtained in distal cuttings planted in peat moss + sand medium. Investigating the effect of application of IBA on distal cuttings grown in seven media selected from the first experiment also showed that cuttings grown in peat moss + perlite and water media had the highest and lowest number of roots, respectively. Cuttings treated with $0 \mathrm{mg} \mathrm{L}^{-1} \mathrm{IBA}$ and grown in water medium showed the greatest root length and length of the longest root. While, the highest root fresh and dry weights were observed under treatment of $500 \mathrm{mg} \mathrm{L}^{-1} \mathrm{IBA}$ in peat moss + sand medium. Overall, distal cuttings treated with a concentration of 500 $\mathrm{mg} \mathrm{L}^{-1} \mathrm{IBA}$ and grown in the rooting medium of peat moss + perlite, followed by peat moss + sand medium were the best treatments for pepino vegetative propagation.

\section{Effect of rooting medium and cutting type on rooting and growth characteristics of cuttings}

\section{Number of roots}

Culture medium and cutting type had a significant effect on the total number of roots, while the interaction of medium $\times$ cutting type on this trait was not significant (Table 1). Based on the results of means comparison of simple effect of culture medium, the highest average number of roots (40.5) was observed in cuttings planted in peat moss + perlite rooting medium with no statistical significant difference from peat moss + sand. The lowest number of roots was obtained in peat moss + cocopeat medium. In other words, the number of roots in cuttings planted in peat moss + perlite and peat moss + sand was 1.7 and 2 times higher than the number of roots observed in peat moss + cocopeat medium, respectively (Fig. 2). The results of the simple effect of cuttings type showed that distal cuttings were more effective than middle ones so that the average number of roots in distal cuttings (31.4) was approximately 1.5 times that of middle ones (21.5).

\section{Average root length, length of the longest root and stem length}

Root length and length of the longest root were significantly affected by the culture medium, type of cutting and the interaction of culture medium $\times$ cutting type, while stem length was only affected by the interaction of culture medium $\times$ cutting type (Table 1). The results obtained from means comparison of the interaction of culture medium $\times$ cutting type showed that the highest averages of root length and length of the longest root were related to distal cuttings in water, while the lowest averages of root length and length of the longest root were observed, respectively, in middle and distal cuttings planted in peat moss + cocopeat medium. Besides, the greatest stem length was observed in cuttings planted in peat moss + sand medium and the shortest stem length was related to the cuttings planted in peat moss + perlite medium (Table 1).

The results of analysis of variance showed that fresh and dry weights of root were significantly affected by culture medium, cutting type and interaction of culture medium $\times$ cutting type, while fresh weight of the plant was affected only by culture medium and interaction of the culture medium $\times$ cutting type and plant dry weight index 
was only affected by the culture medium $\times$ cutting type (Table 2 ). Based on the results of means comparison of the data, the greatest root and plant dry weights and plant fresh weight were related to distal cutting planted in peat moss + sand, while the lowest root dry weight was related to middle cuttings planted in cocopeat + perlite medium and the lowest fresh and dry weights of the plant were recorded in distal cuttings planted in cocopeat + perlite medium. Furthermore, the highest root fresh weight was related to distal cuttings planted in peat moss + perlite medium and the lowest root fresh weight was recorded in the middle cuttings planted in cocopeat + perlite and peat moss substrates (Table 2).

Table 1. Effect of culture medium and cutting type on total number of root, root length of the cuttings, length of the longest root and length of the stem

\begin{tabular}{|c|c|c|c|c|c|}
\hline Culture medium & Cutting type & $\begin{array}{c}\text { Total number of } \\
\text { root }\end{array}$ & $\begin{array}{l}\text { Root length } \\
(\mathrm{cm})\end{array}$ & $\begin{array}{c}\text { Length of the } \\
\text { longest root }(\mathrm{cm})\end{array}$ & Length of the stem \\
\hline \multirow{2}{*}{ Peat moss } & Distal & $25^{\mathrm{a}}$ & $5.86^{\text {bcde }}$ & $8.50^{\mathrm{ab}}$ & $14.07^{\mathrm{bc}}$ \\
\hline & Middle & $20.33^{\mathrm{a}}$ & $5.93^{\mathrm{bcd}}$ & $6.40^{\mathrm{fg}}$ & $8.58^{\text {efghijk }}$ \\
\hline \multirow{2}{*}{ Perlite } & Distal & $34.33^{\mathrm{a}}$ & $5.44^{\text {cdef }}$ & $7.47^{\text {abcdefg }}$ & $8.98^{\text {fefghi }}$ \\
\hline & Middle & $21^{\mathrm{a}}$ & $4.37^{\text {efghi }}$ & $8.00^{\text {abcde }}$ & $6.75^{\text {ghijkl }}$ \\
\hline \multirow{2}{*}{ Cocopeat } & Distal & $24.33^{\mathrm{a}}$ & $4.31^{\text {fghij }}$ & $7.47^{\text {abcdefg }}$ & $6.52^{\mathrm{hijk}}$ \\
\hline & Middle & $19^{\mathrm{a}}$ & $4.99^{\text {defgh }}$ & $8.40^{\mathrm{abc}}$ & $7.25^{\text {ghijk }}$ \\
\hline \multirow{2}{*}{ Sand } & Distal & $38.33^{\mathrm{a}}$ & $6.83^{\mathrm{abc}}$ & $7.00^{\text {bcdefg }}$ & $7.83^{\text {efghijk }}$ \\
\hline & Middle & $24.5^{\mathrm{a}}$ & $5.38^{\text {cdefg }}$ & $7.60^{\text {abcdef }}$ & $8.75^{\text {efghij }}$ \\
\hline \multirow{2}{*}{ Water } & Distal & $27.33^{\mathrm{a}}$ & $7.78^{\mathrm{a}}$ & $7.67^{\text {abcdef }}$ & $25.17^{\mathrm{a}}$ \\
\hline & Middle & $17.50^{\mathrm{a}}$ & $4.59^{\text {defghi }}$ & $8.15^{\mathrm{abcdd}}$ & $5.75^{\mathrm{jk}}$ \\
\hline \multirow{2}{*}{ Peat moss + Perlite } & Distal & $29.67^{\mathrm{a}}$ & $7.27^{\mathrm{ab}}$ & $6.00^{\mathrm{g}}$ & $16.00^{\mathrm{b}}$ \\
\hline & Middle & $15.00^{\mathrm{a}}$ & $6.09^{\mathrm{bcd}}$ & $7.00^{\text {bcdefg }}$ & $9.75^{\operatorname{defg}}$ \\
\hline \multirow{2}{*}{$\begin{array}{c}\text { Peat moss }+ \\
\text { Cocopeat }\end{array}$} & Distal & $43.67^{\mathrm{a}}$ & $3.08^{\mathrm{ij}}$ & $7.67^{\text {abcdef }}$ & $5.50^{\mathrm{k}}$ \\
\hline & Middle & $37.33^{\mathrm{a}}$ & $2.79^{j}$ & $6.50^{\mathrm{efg}}$ & $7.75^{\text {efghijk }}$ \\
\hline \multirow{2}{*}{ Peat + Sand } & Distal & $24.67^{\mathrm{a}}$ & $5.67^{\mathrm{cdef}}$ & $8.97^{\mathrm{a}}$ & $14.33^{\mathrm{bc}}$ \\
\hline & Middle & $16.00^{\mathrm{a}}$ & $5.83^{\text {bcdef }}$ & $6.90^{\text {cdefg }}$ & $8.67^{\text {efghijk }}$ \\
\hline \multirow{2}{*}{ Perlite + Cocopeat } & Distal & $38.67^{\mathrm{a}}$ & $5.39^{\text {cdefg }}$ & $7.83^{\text {abcdef }}$ & $10.33^{\mathrm{def}}$ \\
\hline & Middle & $30.00^{\mathrm{a}}$ & $3.16^{\mathrm{ij}}$ & $6.67^{\text {defg }}$ & $5.90^{\mathrm{ijk}}$ \\
\hline \multirow{2}{*}{ Perlite + Sand } & Distal & $24.67^{\mathrm{a}}$ & $3.84^{\text {jhij }}$ & $7.50^{\text {abcdefg }}$ & $9.33^{\text {efgh }}$ \\
\hline & Middle & $18.50^{\mathrm{a}}$ & $3.53^{\mathrm{hij}}$ & $7.50^{\text {abcdefg }}$ & $12.67^{\mathrm{cd}}$ \\
\hline \multirow{2}{*}{ Cocopeat + Sand } & Distal & $35.00^{\mathrm{a}}$ & $5.27^{\mathrm{defg}}$ & $7.17^{\text {bcdefg }}$ & $10.17^{\mathrm{def}}$ \\
\hline & Middle & $17.50^{\mathrm{a}}$ & $4.79^{\text {defgh }}$ & $6.75^{\operatorname{defg}}$ & $10.50^{\text {ef }}$ \\
\hline \multicolumn{6}{|c|}{ Significance } \\
\hline \multicolumn{2}{|c|}{ Culture medium } & $* *$ & $* *$ & $* *$ & NS \\
\hline \multirow{2}{*}{\multicolumn{2}{|c|}{$\begin{array}{c}\text { Cutting type } \\
\text { Culture medium * Cutting type }\end{array}$}} & $* *$ & $* *$ & $* *$ & NS \\
\hline & & NS & $*$ & $* *$ & $*$ \\
\hline
\end{tabular}

Means with the same letters in each column were not significantly different using least significant difference test (LSD) at $\mathrm{p}<0.05 .{ }^{*},{ }^{* *}$ and NS are significant at $\mathrm{p} \leq 0.05$, at $\mathrm{p} \leq 0.01$ and not significant, respectively

\section{Effect of rooting medium and indole butyric acid on rooting and growth characteristics of seedlings}

\section{Total number of roots}

The results of analysis of variance showed that total root number was significantly affected by culture medium and indole butyric acid, while the interaction effect of culture medium $\times$ indole butyric acid on this index was not significant (Table 3). Based on the results of means comparison, the highest average number of roots (66) was found in peat + perlite culture medium, which showed a significant difference from other substrates, while the lowest mean number of roots (26.7) was seen in water medium 
(Fig. 3). In other words, the number of roots observed in distal cuttings of pepino planted in peat + perlite culture medium was about 2.47 times higher than what was observed in the cuttings planted in water medium (Fig. 3). The simple effect of indole butyric acid hormone showed that the highest number of roots was related to the cuttings treated with indole butyric acid at concentration of $500 \mathrm{mg} / \mathrm{l}$, which showed a statistically significant difference from two other concentrations ( 0 and $1000 \mathrm{mg} / \mathrm{l})$ (Fig 4).

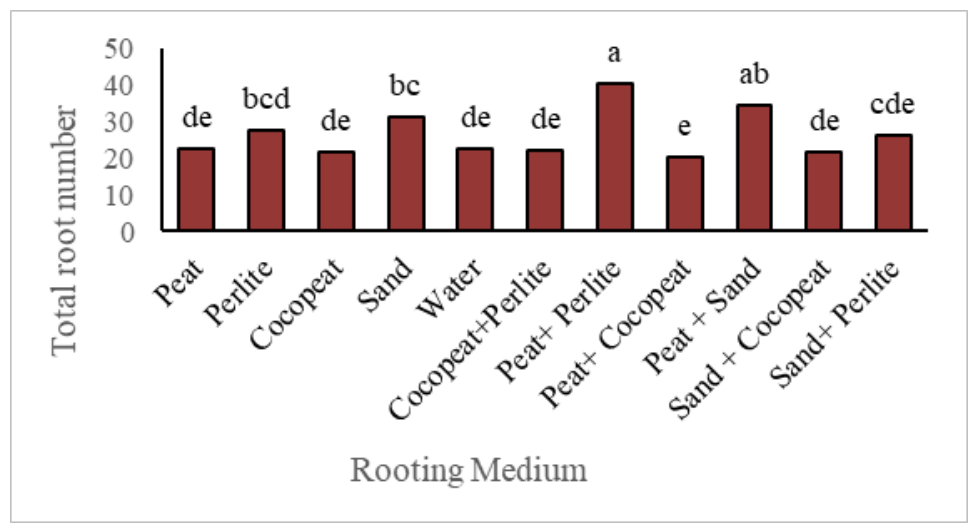

Figure 2. Effect of culture media on root number

Table 2. Effect of culture medium and cutting type on root and plant fresh and dry weights

\begin{tabular}{|c|c|c|c|c|c|}
\hline Culture medium & Cutting type & $\begin{array}{l}\text { Root fresh weight } \\
\text { (g) }\end{array}$ & Root dry weight (g) & \begin{tabular}{|c|} 
Plant fresh weight \\
$(\mathrm{g})$
\end{tabular} & $\begin{array}{c}\text { Plant dry weight } \\
\text { (g) }\end{array}$ \\
\hline \multirow[b]{2}{*}{ Peat moss } & Distal & $0.233^{\mathrm{bc}}$ & $0.026^{\mathrm{bcd}}$ & $1.253^{\mathrm{ab}}$ & $0.145^{\mathrm{ab}}$ \\
\hline & Middle & $0.030^{\mathrm{h}}$ & $0.013^{\text {fghijk }}$ & $0.690^{\mathrm{fg}}$ & $0.138^{\mathrm{ab}}$ \\
\hline \multirow[b]{2}{*}{ Perlite } & Distal & $0.120^{\text {defg }}$ & $0.014^{\text {fghijk }}$ & $0.833^{\text {cdefg }}$ & $0.104^{\text {bc }}$ \\
\hline & Middle & $0.065^{\mathrm{efgh}}$ & $0.008^{\mathrm{jk}}$ & $0.915^{\text {bcdef }}$ & $0.132^{\mathrm{ab}}$ \\
\hline \multirow{2}{*}{ Cocopeat } & Distal & $0.107^{\text {defgh }}$ & $0.009^{\mathrm{ijk}}$ & $0.730^{\mathrm{efg}}$ & $0.098^{\mathrm{bc}}$ \\
\hline & Middle & $0.185^{\mathrm{cd}}$ & $0.013^{\text {fghijk }}$ & $1.085^{\text {bcde }}$ & $0.168^{\mathrm{a}}$ \\
\hline \multirow{2}{*}{ Sand } & Distal & $0.140^{\text {cde }}$ & $0.016^{\text {efghijk }}$ & $0.770^{\text {defg }}$ & $0.097^{\mathrm{bc}}$ \\
\hline & Middle & $0.080^{\text {efgh }}$ & $0.008^{\mathrm{jk}}$ & $0.990^{\text {bcdef }}$ & $0.164^{\mathrm{a}}$ \\
\hline \multirow{3}{*}{ Water } & Distal & $0.107^{\text {defgh }}$ & $0.024^{\text {cde }}$ & $0.733^{\mathrm{efg}}$ & $0.167^{\mathrm{a}}$ \\
\hline & Middle & $0.045^{\mathrm{fgh}}$ & $0.011^{\mathrm{jhijk}}$ & $0.650^{\mathrm{fg}}$ & $0.105^{\mathrm{bc}}$ \\
\hline & Middle & $0.135^{\text {cde }}$ & $0.021^{\mathrm{def}}$ & $0.870^{\text {cdefg }}$ & $0.144^{\mathrm{ab}}$ \\
\hline \multirow[b]{2}{*}{ Peat moss + Perlite } & Distal & $0.317^{\mathrm{a}}$ & $0.035^{\mathrm{ab}}$ & $1.193^{\mathrm{abc}}$ & $0.147^{\mathrm{ab}}$ \\
\hline & Middle & $0.135^{\text {cde }}$ & $0.021^{\text {def }}$ & $0.870^{\text {cdefg }}$ & $0.144^{\mathrm{ab}}$ \\
\hline \multirow{2}{*}{$\begin{array}{c}\text { Peat moss }+ \\
\text { Cocopeat }\end{array}$} & Distal & $0.067^{\mathrm{efgh}}$ & $0.016^{\text {efghijk }}$ & $1.247^{\mathrm{ab}}$ & $0.161^{\mathrm{a}}$ \\
\hline & Middle & $0.040^{\mathrm{gh}}$ & $0.008^{\mathrm{jk}}$ & $1.125^{\mathrm{bcd}}$ & $0.125^{\mathrm{abc}}$ \\
\hline \multirow[b]{2}{*}{ Peat+ Sand } & Distal & $0.293^{\mathrm{ab}}$ & $0.038^{\mathrm{a}}$ & $1.567^{\mathrm{a}}$ & $0.172^{\mathrm{a}}$ \\
\hline & Middle & $0.142^{\text {cde }}$ & $0.032^{\mathrm{ab}}$ & $0.870^{\text {cdefg }}$ & $0.118^{\mathrm{abc}}$ \\
\hline \multirow{2}{*}{ Perlite + Cocopeat } & Distal & $0.063^{\mathrm{efgh}}$ & $0.010^{\mathrm{hijk}}$ & $0.530^{\mathrm{g}}$ & $0.070^{c}$ \\
\hline & Middle & $0.030^{\mathrm{h}}$ & $0.007^{\mathrm{k}}$ & $0.755^{\text {defg }}$ & $0.140^{\mathrm{ab}}$ \\
\hline \multirow{2}{*}{ Perlite + Sand } & Distal & $0.130^{\text {def }}$ & $0.018^{\text {defghi }}$ & $0.867^{\text {bcdef }}$ & $0.123^{\mathrm{abc}}$ \\
\hline & Middle & $0.105^{\text {defgh }}$ & $0.020^{\mathrm{defg}}$ & $0.920^{\text {cdefg }}$ & $0.139^{\mathrm{ab}}$ \\
\hline \multirow{2}{*}{ Cocopeat + Sand } & Distal & $0.130^{\text {def }}$ & $0.019^{\text {defgh }}$ & $0.840^{\text {cdefg }}$ & $0.120^{\mathrm{abc}}$ \\
\hline & Middle & $0.085^{\text {efgh }}$ & $0.017^{\text {defghij }}$ & $0.935^{\text {bcdef }}$ & $0.162^{\mathrm{a}}$ \\
\hline \multicolumn{2}{|c|}{ Significance } & & & & \\
\hline \multicolumn{2}{|c|}{ Culture medium } & $* *$ & $* *$ & $* *$ & NS \\
\hline \multicolumn{2}{|c|}{ Cutting type } & $* *$ & $* *$ & NS & NS \\
\hline \multicolumn{2}{|c|}{ Culture medium *Cutting type } & $* *$ & $*$ & $* *$ & $* *$ \\
\hline
\end{tabular}

Means with the same letters in each column were not significantly different using least significant difference test (LSD) at $\mathrm{p}<0.05 .{ }^{*},{ }^{* *}$ and NS are significant at $\mathrm{p} \leq 0.05$, at $\mathrm{p} \leq 0.01$ and not significant, respectively 
Table 3. Effect of culture medium and indole butyric acid on total number of root, root length, longest root, root quality and stem length

\begin{tabular}{|c|c|c|c|c|c|c|}
\hline $\begin{array}{l}\text { Culture } \\
\text { medium }\end{array}$ & IBA & \begin{tabular}{|c|}
$\begin{array}{c}\text { Total number } \\
\text { of root }\end{array}$ \\
\end{tabular} & Root length $(\mathrm{cm})$ & $\begin{array}{c}\text { Longest root } \\
(\mathrm{cm})\end{array}$ & $\begin{array}{l}\text { Root fresh } \\
\text { weight (g) }\end{array}$ & $\begin{array}{r}\text { Root dry } \\
\text { weight (g) }\end{array}$ \\
\hline \multirow{3}{*}{ Peat moss } & 0 & $30.50^{\mathrm{a}}$ & $5.86^{\mathrm{bcd}}$ & $13.07^{\text {cde }}$ & $0.27^{\mathrm{abc}}$ & $0.025^{\mathrm{cd}}$ \\
\hline & 500 & $39.33^{\mathrm{a}}$ & $6.01^{\text {bcd }}$ & $11.25^{\text {def }}$ & $0.30^{\mathrm{ab}}$ & $0.024^{\text {cde }}$ \\
\hline & 1000 & $36.66^{\mathrm{a}}$ & $4.49^{\text {efgh }}$ & $11.83^{\mathrm{cdef}}$ & $0.25^{\mathrm{abc}}$ & $0.030^{\mathrm{bc}}$ \\
\hline \multirow{3}{*}{ Perlite } & 0 & $34.33^{\mathrm{a}}$ & $5.27^{\text {bcdef }}$ & $8.98^{\mathrm{fgh}}$ & $0.12^{\text {ef }}$ & $0.014^{\mathrm{ofg}}$ \\
\hline & 500 & $42.16^{\mathrm{a}}$ & $4.68^{\text {defgh }}$ & $10.96^{\mathrm{def}}$ & $0.11^{\mathrm{f}}$ & $0.014^{\mathrm{efg}}$ \\
\hline & 1000 & $41.25^{\mathrm{a}}$ & $5.00^{\text {cdefg }}$ & $11.75^{\text {cdef }}$ & $0.13^{\text {def }}$ & $0.013^{\mathrm{fg}}$ \\
\hline \multirow{3}{*}{ Sand } & 0 & $38.33^{\mathrm{a}}$ & $5.46^{\text {bcdef }}$ & $7.33^{\mathrm{h}}$ & $0.14^{\mathrm{def}}$ & $0.013^{\mathrm{fg}}$ \\
\hline & 500 & $46.66^{\mathrm{a}}$ & $3.85^{\mathrm{gh}}$ & $7.63^{\mathrm{gh}}$ & $0.12^{\mathrm{ef}}$ & $0.012^{\mathrm{g}}$ \\
\hline & 1000 & $38.00^{\mathrm{a}}$ & $4.88^{\text {defgh }}$ & $10.75^{\operatorname{defg}}$ & $0.16^{\text {def }}$ & $0.018^{\operatorname{defg}}$ \\
\hline \multirow{3}{*}{ Water } & 0 & $27.16^{\mathrm{a}}$ & $7.78^{\mathrm{a}}$ & $24.83^{\mathrm{a}}$ & $0.11^{\mathrm{f}}$ & $0.024^{\mathrm{cd}}$ \\
\hline & 500 & $29.66^{\mathrm{a}}$ & $5.47^{\text {bcdef }}$ & $13.33^{\text {cde }}$ & $0.08^{\mathrm{f}}$ & $0.015^{\operatorname{defg}}$ \\
\hline & 1000 & $23.5^{\mathrm{a}}$ & $5.54^{\text {bcde }}$ & $11.17^{\mathrm{def}}$ & $0.12^{\mathrm{ef}}$ & $0.019^{\text {defg }}$ \\
\hline \multirow{3}{*}{$\begin{array}{l}\text { Peat moss + } \\
\text { Perlite }\end{array}$} & 0 & $51.83^{\mathrm{a}}$ & $6.44^{\mathrm{b}}$ & $14.00^{\mathrm{cd}}$ & $0.27^{\mathrm{abc}}$ & $0.035^{\mathrm{ab}}$ \\
\hline & 500 & $66.66^{\mathrm{a}}$ & $5.73^{\text {bdef }}$ & $10.83^{\operatorname{defg}}$ & $0.20^{\text {cde }}$ & $0.024^{\mathrm{cd}}$ \\
\hline & 1000 & $49.58^{\mathrm{a}}$ & $5.27^{\text {bcdef }}$ & $11.70^{\text {cdef }}$ & $0.15^{\text {def }}$ & $0.018^{\text {defg }}$ \\
\hline \multirow{3}{*}{$\begin{array}{l}\text { Peat moss + } \\
\text { Sand }\end{array}$} & 0 & $38.66^{\mathrm{a}}$ & $5.01^{\text {cdefg }}$ & $14.83^{\mathrm{bc}}$ & $0.33^{\mathrm{ab}}$ & $0.031^{\mathrm{ab}}$ \\
\hline & 500 & $50.00^{\mathrm{a}}$ & $6.26^{\mathrm{bc}}$ & $17.50^{\mathrm{b}}$ & $0.34^{\mathrm{a}}$ & $0.041^{\mathrm{a}}$ \\
\hline & 1000 & $31.66^{\mathrm{a}}$ & $5.85^{\mathrm{bcd}}$ & $10.67^{\mathrm{efg}}$ & $0.21^{\mathrm{cd}}$ & $0.020^{\text {defg }}$ \\
\hline \multirow{3}{*}{ Perlite + Sand } & 0 & $36.66^{\mathrm{a}}$ & $3.84^{\mathrm{gh}}$ & $9.33^{\mathrm{fgh}}$ & $0.13^{\text {def }}$ & $0.018^{\text {defg }}$ \\
\hline & 500 & $40.83^{\mathrm{a}}$ & $4.14^{\mathrm{fgh}}$ & $10.33^{\text {efgh }}$ & $0.16^{\mathrm{def}}$ & $0.023^{\text {cdef }}$ \\
\hline & 1000 & $36.00^{\mathrm{a}}$ & $3.61^{\mathrm{h}}$ & $9.50^{\text {fgh }}$ & $0.14^{\text {def }}$ & $0.022^{\text {cdef }}$ \\
\hline \multicolumn{7}{|c|}{ Significance } \\
\hline \multirow{3}{*}{\multicolumn{2}{|c|}{$\begin{array}{l}\text { Culture medium } \\
\text { IBA }\end{array}$}} & $* *$ & $* *$ & $* *$ & $* *$ & $* *$ \\
\hline & & $* *$ & $*$ & $* *$ & NS & NS \\
\hline & Culture medium * IBA & NS & $*$ & $* *$ & $*$ & $* *$ \\
\hline
\end{tabular}

Means with the same letters in each column were not significantly different using least significant difference test (LSD) at $\mathrm{p}<0.05 .{ }^{*},{ }^{* *}$ and NS are significant at $\mathrm{p} \leq 0.05$, at $\mathrm{p} \leq 0.01$ and not significant, respectively

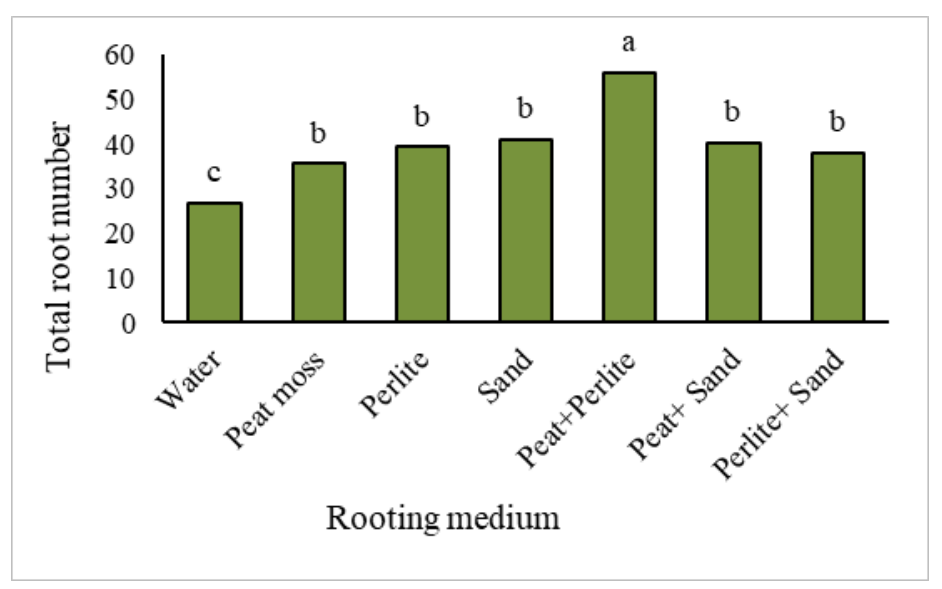

Figure 3. Effect of rooting substrate on root number

\section{Average root length and length of the longest root}

Mean root length and length of the longest root were significantly affected by the culture medium, indole butyric acid and culture medium $\times$ indole butyric acid interaction (Table 3). Among the different treatments, the greatest root length and the longest root length were related to $0 \mathrm{mg} / \mathrm{l}$ indole butyric acid in water, which resulted in 
a statistically significant difference compared to other treatments. The lowest root length and the shortest root length were obtained in $1000 \mathrm{mg} / \mathrm{l}$ indole butyric acid in perlite + sand medium and $0 \mathrm{mg} / \mathrm{l}$ indole butyric acid in sand medium (Table 3 ).

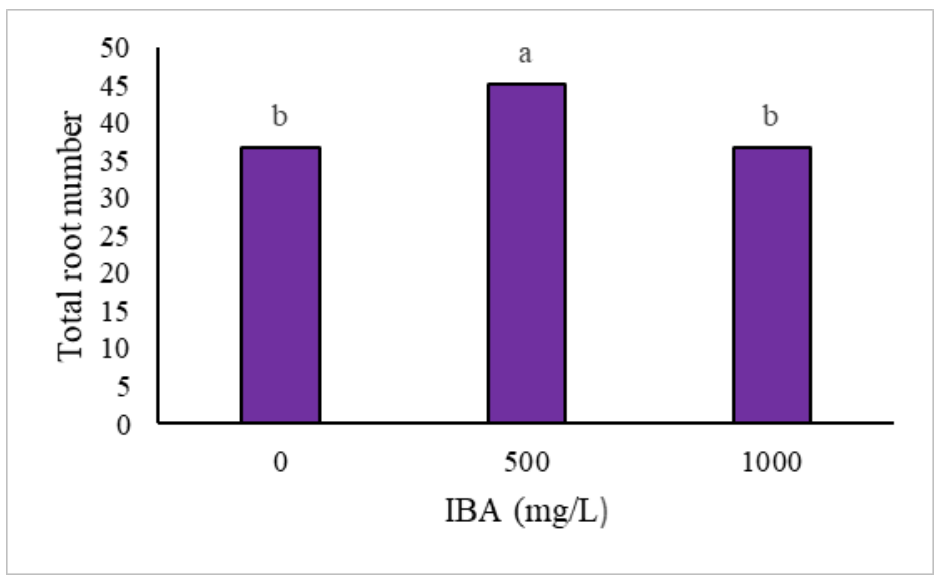

Figure 4. Effect of indole butyric acid on root number

\section{Fresh and dry weights of root}

Culture medium and culture medium $x$ indole butyric acid interaction had a significant effect on root fresh and dry weights, while the simple effect of indole butyric acid on these two indices was not statistically significant (Table 3). The results of culture medium $\times$ indole butyric acid interaction showed that the highest root fresh and dry weights were due to the cuttings treated with $500 \mathrm{mg} / \mathrm{l}$ indole butyric acid in peat moss + sand medium. Moreover, the lowest root fresh and dry weights were recorded in the cuttings treated with indole butyric acid at concentration of $500 \mathrm{mg} / \mathrm{l}$ in water and sand substrates (Table 3).

\section{Discussion}

The results of the first experiment indicated better rooting of distal cuttings of pepino in comparison with the middle cuttings, and also greater suitability of peat moss + sand and peat moss + perlite substrates for rooting and vegetative growth of seedlings compared to other substrates. The significant effect of culture medium on different root characteristics such as number and length of root (Ercisli et al., 2005), weight, thickness, length and volume of root (Ahmad et al., 2000), and number of primary roots and amount of root dry matter (Kreen et al., 2002) has been reported in different studies. Culture medium is one of the most important indicators for successful rooting of cutting. Cuttings of azalea, privet and almond in a mixture with equal ratios of peat and sand had a remarkably good rooting, indicating that this combination (peat + sand) can be very useful for many cuttings which have poor rooting in either peat or sand (Hitchcock, 1928). Peat, perlite and sand substrates for rooting of tomato cuttings were more suitable than sand + soil + organic fertilizer mixture, so that the highest number of leaves and greatest fresh and dry weights of seedling were observed in peat medium and the longest root length and greatest seedling fresh weight were reported in peat and sand rooting media (Gül et al., 1993). Moreover, the increase found in rooting percentage and 
number of primary root in kiwifruit cuttings planted in peat + perlite medium was associated to proper water holding of this medium (Ercişli et al., 2002). Due to having suitable physical and chemical characteristics such as density, porosity, air capacity, water holding capacity, $\mathrm{pH}$, electrical conductivity, cation exchange capacity and carbon to nitrogen ratio, peat is a suitable medium for planting most horticultural species (Abad et al., 2001). The maintenance of adequate ventilation in the rooting environment, along with reduced water losses from cuttings, is one of the important tasks of propagation systems. On the one hand, the presence of proper ventilation around the roots in culture media containing peat moss is effective in the induction and growth of roots in cuttings (Hartman et al., 1990; Jinks, 1995), and, on the other hand, the positive and desirable effect of peat moss + sand on rooting can be due to better water holding by this mixture compared to sand, as well as due to other potential benefits affected by peat moss (Hitchcock, 1928). Superiority of peat moss can be due to high cation exchange capacity and appropriate moisture holding. Use of perlite in combination with traditional media containing peat can be effective in plant growth and development due to better aeration (Smith and Hall, 1994).

The results of this study showed that root length in water medium was longer than other rooting media. In line with the results obtained in this study, Nemati and Tehranifar (2007) also reported that the total root length of pepino cuttings planted in perlite and water media was greater than that in other substrates. However, rooted cuttings in water medium did not have good establishment in soil. The effect of rooting media on the extension of the appeared roots was more than induction of rooting (Long, 1932). Although pepino can withstand flood conditions for several days (Prohens et al., 1996), formation of long roots in water medium can be a sign of flood stress (Gibberd et al., 2001; Grzesiak et al., 2014). These long roots are likely to be aerotropic roots that plant expands under flood stress conditions to search for air and oxygen (Gibberd et al., 2001).

Cutting position affects the rate of rooting success, so that better rooting of distal cuttings compared to middle ones has been reported in different plants, such as olive (Aboutalebi Jahromi and Hassanpoor, 2003) and neem (Palanisamy and Kumar, 1997), which is consistent with the results obtained in this study. As the plant grows older, the production of rooting inhibitors increases and there is a direct correlation between the reduction of rooting and tissues of lower cuttings (Paton et al., 1970). Phenols act as auxin cofactor, and reduction in rooting potential, along with aging of plants, can be due to the reduction of phenolic compounds (Khandan-Mirkohi et al., 2015). The absence of terminal bud in cutting and consequently depriving of cutting from internal auxin can lead to a decrease in the number of cells in root primordia. On the other hand, the aging of the root primordia and increase in the number of its cells reduce the effect of internal auxin, indicating greater rooting in juvenile cuttings with terminal bud (Haissig, 1972; Khandan-Mirkohi et al., 2015). Generally, the increase in rooting in distal cuttings containing terminal buds relative to cuttings with no bud can be attributed to high concentrations of internal rooting stimulator produced in the terminal bud and hence the pre-formation of a number of root initials affected by these materials (Davies and Hartmann, 1988; Hartman et al., 1990). Better rooting of distal cuttings in comparison with the middle ones can be due to the presence of higher auxin content at distal end of the shoot, so it is possible that auxin concentration decreases with increased distance from shoot tip and, consequently, rooting decreases (Palanisamy and Kumar, 1997). 
Based on the results of this study, rooting rate of pepino cuttings was influenced by the use of auxin hormone (IBA). The ability of cuttings for rooting is dependent upon phenolic compounds, enzymes and their auxin content (Loreti and Morini, 1985), so that success in rooting of some carnation species without application of plant growth regulators was related to their internal auxin (Guerrero et al., 1999). Auxin has a positive role in induction of rooting, formation of root initials, and increase of speed and percentage of cuttings rooting. Despite the synthesis of auxin in various plant organs (including young shoots and leaves), application of synthetic auxin for successful rooting and prevention of cutting death is useful (Štefančič et al., 2007; Kasim and Rayya, 2009). Through stimulating pericycle cells in the upper parts of root hairs, auxin hormone can stimulate the division of cell in this region and eventually lead to root formation (Hillman, 1984; Davies, 1995; Laskowski et al., 1995). Generally, the positive effect of auxin on rooting can be attributed to the increase of auxin-based food supply, increase of protein content and peroxidase enzyme activity (Husen and Pal, 2007) as well as its role in stimulating the division of the first cell of root initials (Hartman et al., 1990; Loach, 1996). In addition, the effect of rooting auxin hormone on the increase of root length can be due to the effect of this growth regulator on the stimulation of cell division.

Although it has been reported that pepino, due to the easy rooting of its cuttings, is mainly propagated vegetatively by using cutting and in most cases it is not necessary to use mist system or plant hormones (National Research Council, 1989; Spooner et al., 1993; Prohens et al., 1996), there is a report regarding unsuccessful rooting and vegetative propagation by using cuttings obtained from seedlings of Ramses and Consuelo varieties in Iran (Nemati and Tehranifar, 2007). Furthermore, the results of this study showed that application of rooting hormones can increase the success rate of pepino vegetative propagation. Use of IBA (especially at concentration of $500 \mathrm{mg} / \mathrm{l}$ ) improved rooting and grwoth characteristics of seedlings in the present study. On the other hand, it has been shown that application of high concentration of IBA (1000 mg/l) in comparison with concentration of $500 \mathrm{mg} / \mathrm{l}$ decreased rooting and growth characteristics of seedlings, showing bell characteristic of hormones. Although IBA is one of the most effective compounds stimulating rooting in many species (Hartmann and Kester, 1990), its effect can vary based on the type of cuttings (Tworkoski and Takeda, 2007) and the concentration used. It has been reported that use of IBA at concentration of $1000 \mathrm{mg} / \mathrm{l}$ reduced the number of leaves and root fresh weight in lateral cuttings of tomato compared with the control (distilled water) (Gül et al., 1993). High concentrations of auxin can cause degradation of the basal tissues of cuttings, interference in hormonal balance in plant, damage to the cells, reduction of rooting, and inhibition of buds growth and even shoot development (Hartmann and Kester, 1990; Blythe et al., 2004; Ranjbar and Ahmadi, 2016).

\section{Conclusion}

Cutting position and type of culture medium influenced the success rate and percentage of rooting and different growth characteristics (number of roots, root length, length of the longest root, stem length, and fresh and dry weights of root and plant) in pepino cuttings. In conclusion, the results of the first experiment indicated the superiority of terminal cuttings over the middle ones and also more suitability of peat moss + perlite and peat moss + sand substrates compared to other substrates for the 
propagation of pepino. Study of the effect of auxin hormone and rooting medium in the second experiment showed that treatment of the cuttings with $500 \mathrm{mg} / \mathrm{l} \mathrm{IBA}$ was more effective than concentration of $1000 \mathrm{mg} / \mathrm{l}$. Peat moss + perlite and peat moss + sand substrates were more suitable than other substrates. In general, it was found in this study that the best treatment combination to increase the rooting of cuttings and to improve the growth characteristics of pepino seedlings is the use of terminal cutting, rooting hormone of IBA at concentration of $500 \mathrm{mg} / \mathrm{l}$, and planting of cuttings in peat moss + perlite and peat moss + sand media. Finally, it is highly recommended that future investigators compare rooting of different cultivars of pepino simultaneously under different light and carbon dioxide regimes.

Acknowledgements. The authors would like to thank the staff of the Department of Horticulture and Green Space Engineering and Research Center for Plant Sciences of Ferdowsi University of Mashhad for cooperation and provision of greenhouse and laboratory facilities for this project.

\section{REFERENCES}

[1] Abad, M., Noguera, P., Burés, S. (2001): National inventory of organic wastes for use as growing media for ornamental potted plant production: case study in Spain. - Bioresource Technology 77(2): 197-200.

[2] Aboutalebi Jahromi, A., Hassanpoor, A. (2003): Investigating the effects of time, location of cutting, rooting media and auxin on rooting of olive cuttings of Zard cultivar. - Iranian Journal of Horticultural Science and Technology 4(3-4): 105-114.

[3] Ahmad, N., Ishtiaq, M., Zeb, A. (2000): Response of bottle brush seedling to different soil media. - Sarhad Journal of Agriculture 16(5): 503-509.

[4] Bhardwaj, H. L., Hankins, A., Mebrahtu, T., Mullins, J., Rangappa, M., Abaye, O., Welbaum, G. E. (1996): Alternative crops research in Virginia. - In: Janick, J. (ed.) Progress in new crops. ASHS Press, Alexandria, VA. p. 87-96.

[5] Blythe, E. K., Sibley, J. L., Ruter, J. M., Tilt, K. M. (2004): Cutting propagation of foliage crops using a foliar application of auxin. - Scientia Horticulturae 103(1): 31-37.

[6] Cantliffe, D. J., Funes, J., Jovicich, E., Paranje, A., Rodriguez, J., Shaw, N. (2003): Media and containers for greenhouse soilless grown cucumber, melons, peppers and strawberries. - Acta Horticulturae 614: 199-203.

[7] Davies, F. T., Hartmann, H. T. (1988): The physiological basis of adventitious root formation. - Acta Horticulturae 227: 113-120.

[8] Davies, P. J. (1995): Introduction. The Plant Hormones. - Kluwer Academic Publishers pp. 1-38.

[9] Douglass, F. J., Thomas, D. L., Luna, T. (2009): Growing Media. - In: Dumroese, R. K., Luna, T., Landis, T. D. (eds.) Nursery manual for native plants: A guide for tribal nurseries. Volume 1: Nursery management. Agriculture Handbook 730. Washington, D.C.: U.S. Department of Agriculture, Forest Service. p. 77-93.

[10] Ercişli, S., Anapali, Ö., Eşitken, A., Şahin, Ü. (2002): The effects of IBA, rooting media and cutting collection time on rooting of kiwifruit. - Gartenbauwissenschaft 67(1): 34-38.

[11] Ercisli, S., Sahin, U., Esitken, A., Anapali, O. (2005): Effects of some growing media on the growth of strawberry cvs.'Camarosa'and'Fern'. - Acta Agrobotanica 58(1).

[12] Gibberd, M. R., Gray, J. D., Cocks, P. S., Colmer, T. D. (2001): Waterlogging tolerance among a diverse range of Trifolium accessions is related to root porosity, lateral root formation and 'aerotropic rooting'. - Annals of Botany 88(4): 579-589.

[13] Grzesiak, M. T., Ostrowska, A., Hura, K., Rut, G., Janowiak, F., Rzepka, A., Hura, T., Grzesiak, S. (2014): Interspecific differences in root architecture among maize and 
triticale genotypes grown under drought, waterlogging and soil compaction. - Acta Physiologiae Plantarum 36(12): 3249-3261.

[14] Guerrero, J. R., Garrido, G., Acosta, M., Sanchez-Bravo, J. (1999): Influence of 2, 3, 5triiodobenzoic acid and 1-N-naphthylphthalamic acid on indoleacetic acid transport in carnation cuttings: relationship with rooting. - Journal of Plant Growth Regulation 18(4): 183-190.

[15] Gül, A., Tüzel, Y., Yoltas, T. (1993): Possibilities of using side shoots as propagation material in greenhouse tomato production. - II Symposium on Protected Cultivation of Solanacea in Mild Winter Climates 366: 271-278.

[16] Gül, A., Eroğul, D., Ongun, A. R. (2005): Comparison of the use of zeolite and perlite as substrate for crisp-head lettuce. - Scientia Horticulturae 106(4): 464-471.

[17] Haissig, B. E. (1972): Meristematic activity during adventitious root primordium development: influences of endogenous auxin and applied gibberellic acid. - Plant physiology 49(6): 886-892.

[18] Hartman, H. T., Kester, D. E., Davies, F. T. (1990): Plant propagation: Principleand Practices. - Prentice-Hall. 647 pp.

[19] Hernando, J. E., Leon, J. (1994): Neglected crops from a different perspective. - Plant Production and Protection Series No. 26. FAO, Rome Italy. p. 181-191.

[20] Hillman, J. R. (1984): Apical dominance. - In: Wilkins, M. B. (ed.) Advanced Plant Physiology. London: Pitman Publishing, pp. 127-148.

[21] Hitchcock, A. E. (1928): Effect of peat moss and sand on rooting response of cuttings. Botanical Gazette 86(2): 121-148.

[22] Hrbans, L., Hankins, A., Mebrahtu, T., Mullins, J., Rangappa, M. (1996): Alternative crops research in Virginia. - Progress in new crops. ASHS press p: 87-96.

[23] Husen, A., Pal, M. (2007): Metabolic changes during adventitious root primordium development in Tectona grandis Linn. f. (teak) cuttings as affected by age of donor plants and auxin (IBA and NAA) treatment. - New Forests 33(3): 309-323.

[24] Jinks, R. L. (1995): The effects of propagation environment on the rooting of leafy cuttings of ash (Fraxinus excelsior L.), sycamore (Acer pseudoplatanus L.) and sweet chestnut (Castanea sativa Mill.). - New Forests 10: 183-195.

[25] Johnson, H., Hochmuth, G. J., Maynard, D. N. (1985): Soilless culture of greenhouse vegetables. - Bulletin/Florida Cooperative Extension Service (USA).

[26] Kasim, N. E., Rayya, A. (2009): Effect of different collection times and sometreatments on rooting and chemical interminal constituents of bitter almond hardwood cutting. Journal of Agriculture and Biological Sciences 5(2): 116-122.

[27] Khandan-Mirkohi, A., Moshrefi-Araghi, A., Haghdoost, L., Rashid- Rostami, F., Sahraii, S. (2015): The effect of rooting medium, cutting type and auxin (IBA) treatment on propagation of Arizona cypress (Cupressus arizonica var. glabra). - Journal of Science and Technology of Greenhouse Culture 5(4): 193-202. (In Persian).

[28] Kreen, S., Svensson, M., Rumpunen, K. (2002): Rooting of clematis micro shoots and stem cuttings in different substrates. - Scientia Horticulturae 96: 351-357.

[29] Laskowski, M. J., Williams, M. E., Nusbaum, H. C., Sussex, I. M. (1995): Formation of lateral root meristems is a two-stage process. - Development 121: 3303-3310.

[30] Loach, K. (1996): Environmental conditions for rooting cutting: importantce, measurment and control. - Acta Horticulturae 374: 632-636.

[31] Long, J. C. (1932): The influence of rooting media on the character of roots produced by cuttings. - American Society for Horticultural Science 29(3): 352-355.

[32] Loreti, F., Morini, S. (1985): Rooting responses to BS, B2 and GF677 rootstocks cuttings. - Acta Horticulturae 173: 261-269.

[33] National Research Council. (1989): Lost crops of the incas: little-known plants of the Andes with promise for worldwide cultivation. - Washington, DC: The National Academies Press. 
[34] Nemati, H., Tehranifar, A. (2007): Investigation of sexual and asexual propagation of a new vegetable called pepino in Iran (Solanum muricatum, Atio, pepino). - Mashhad, Journal of Agricultural Science and Technology 21: 3-9. (In Persian).

[35] Palanisamy, K., Kumar, P. (1997): Effect of position, size of cuttings and environmental factors on adventitious rooting in neem (Azadirachta indica A. Juss). - Forest Ecology and Management 98(3): 277-280.

[36] Paton, D. M., Willing, R. R., Nicholls, W., Pryor, L. D. (1970): Rooting of stem cuttings of Eucalyptus: a rooting inhibitor in adult tissue. - Australian Journal of Botany 18(2): 175-183.

[37] Pauli, R. (1988): Micropropagation of pepinos (Solanum muricalum Ait.). - Acta Horticulturae 227: 387-389.

[38] Pierik, R. L. M. (1997): Micropropagation of Solanum muricatum Ait. (Pepino). - HighTech and Micropropagation V: 160-172.

[39] Prohens, J., Ruiz, J. J., Nuez, F. (1996): The pepino (Solanum muricatum, Solanaceae): A "new" crop with a history. - Economic Botany 50: 355-368.

[40] Prohens, J., Nuez, F. (1999): Strategies for breeding a new greenhouse crop, the pepino (Solanum muricatum Aiton). - Canadian Journal of Plant Science 79: 269-275.

[41] Prohens, J., Rodríguez-Burruezo, A., Nuez, F. (2005): Utilization of genetic resources for the introduction and adaptation of exotic vegetable crops: The case of pepino (Solanum muricatum, Ait.). - Euphytica 146: 133-142.

[42] Ranjbar, A., Ahmadi, N. (2016): The effects of IBA and NAA, and rooting media on propagation of miniature rose cuttings (Rosa hybrida). - Journal of Horticultural Science 30(3): 250-528. (In Persian).

[43] Schie, W. V. (1997): Standardization of substrates. - International Symposium on Growing Media and Hydroponics 481: 71-78.

[44] Smith, C. A., Hall, D. A. (1994): The development of perlite as a potting substrate for ornamental plants. - Acta Horticulturae 361: 159-166.

[45] Spooner, D. M., Anderson, G. J., Jansen, R. K. (1993): Chloroplast DNA evidence for the interrelationships of tomtoes, potatoes, and pepinos (Solanaceae). - American Journal of Botany 676-688.

[46] Štefančič, M., Štampar, F., Veberič, R., Osterc, G. (2007): The levels of IAA, IAAsp and some phenolics in cherry rootstock 'GiSelA 5'leafy cuttings pretreated with IAA and IBA. - Scientia Horticulturae 112(4): 399-405.

[47] Sudha, G., Priya, M. S., Shree, R. I., Vadivukkarasi, S. (2011): In vitro free radical scavenging activity of raw pepino fruit (Solanum muricatum aiton). - International Journal of Current Pharmaceutical Research 3(2): 137-140.

[48] Tworkoski, T., Takeda, F. (2007): Rooting response of shoot cuttings from three peach growth habits. - Scientia Horticulturae 115(1): 98-100.

[49] Verdonck, O., De Vleeschauwer, D., De Boodt, M. (1982): The influence of the substrate to plant growth. - Acta Horticulturae 126: 251-258. 